\title{
WIARYGODNOŚĆ INFORMACYJNA BANKU - PERSPEKTYWA SENIORA KORZYSTAJĄCEGO Z USŁUG NA RYNKU BANKOWYM
}

\section{Grażyna Szustak $^{*}$ (D) Łukasz Szewczyk $^{* *}$ D \\ BANK'S INFORMATION RELIABILITY - A PERSPECTIVE OF A SENIOR USING SERVICES ON THE BANKING MARKET}

\begin{abstract}
The purpose of the article/hypothesis: The aim of the article is to present the essence of a bank's information reliability and its assessment by a selected group of stakeholders, which are seniors. The conducted study allowed for the positive verification of the following research hypothesis: the bank's information reliability is an important factor that influences the bank's assessment by seniors.

Methodology: The text has been divided into three parts. Two of them are theoretical and the authors focused here on a critical analysis of the literature on the subject. The first one describes the problem of trust in banks and public guarantees as factors influencing the shape of the sector. The second part focuses on presenting important issues related to the broadly understood information in the bank-client relationship. In the empirical part of the article, a questionnaire study was conducted in which the information reliability was assessed from the perspective of seniors using banking services.

Results of the research: The research showed that $75 \%$ of the respondents had in practice encountered a situation in which the bank provided incomplete or false information. Two-thirds of the respondents also emphasized that information credibility is an important element of building trust in a bank. On the other hand, less than half of them indicated that the bank's information message was legible.
\end{abstract}

Keywords: public trust, public guarantees, information reliability, banking sector, senior on the banking services market.

JEL Class: G2, G21.

\footnotetext{
* Dr hab., prof. UE, Uniwersytet Ekonomiczny w Katowicach, e-mail: grazyna.szustak@uekat.pl.

** Dr, Uniwersytet Ekonomiczny w Katowicach, e-mail: lukasz.szewczyk@uekat.pl.
} 


\section{WSTĘP}

Zaufanie klientów jest ważnym elementem, który wpływa na stabilność sektora bankowego. Banki jako instytucje zaufania publicznego pełnią bowiem niezwykle ważną rolę w gospodarce, a ich klienci powinni mieć poczucie, że instytucje te działają w ich szeroko rozumianym interesie. Jednym z ważnych czynników, który kształtuje poziom tego zaufania jest wiarygodność informacyjna banku, która przejawia się przede wszystkim pełną i rzetelną informacją przekazywaną przez banki swoim klientom. Sprzyja to niewątpliwie postrzeganiu banku jako instytucji przejrzystej, kierującej się w swojej działalności zasadami etyki.

Celem artykułu jest przedstawienie istoty wiarygodności informacyjnej banku i jej ocena przez wybraną grupę interesariuszy, którą są seniorzy. Przeprowadzone badanie pozwoliło na pozytywne zweryfikowanie następującej hipotezy badawczej: wiarygodność informacyjna banku jest istotnym czynnikiem, który wpływa na ocenę banku przez seniorów. Artykuł został podzielony na trzy części. W pierwszej $\mathrm{z}$ nich scharakteryzowano problem zaufania do banków, również $\mathrm{w}$ wymiarze prawnym i instytucjonalnym. W drugiej skupiono się na kwestiach dotyczących szeroko rozumianej informacji w relacjach bank i jego klienci. W trzeciej części przedstawiono wyniki ankiety, w której dokonano oceny wiarygodności informacyjnej banku z perspektywy seniorów, jako specyficznej, a zarazem niezwykle istotnej grupy klientów banku.

\section{ZAUFANIE DO BANKÓW. PAŃSTWOWE GWARANCJE ZAUFANIA PUBLICZNEGO DO BANKÓW - UJĘCIE TEORETYCZNE}

Zaufanie, jako kategoria mierzalna i wartość etyczna, ekonomiczna czy społeczna, oznacza założenie uczciwości, niezawodności, odpowiedzialności, wrażliwości stron, a także rzetelnej wiedzy, prawdziwości źródeł i przekazywanych informacji (Młodzik, 2018: 280-282). Można również powiedzieć, że zaufanie to pozytywne oczekiwania wobec siebie i innych (Chryssochoidis, Strada i Krystalli, 2009: 137). Zaufanie jest zatem miarą jakości wzajemnych relacji, m.in. między klientem a organizacją (Hurley, 2006). Oczywistym jest, że każda organizacja musi na zaufanie klienta zapracować, co nie jest zadaniem łatwym. Zaufanie, a idąc dalej świadome zaufanie powinno być normą, zarówno w relacjach międzyludzkich, jak i w relacjach klient-podmiot gospodarujący. Zaufanie, uważane za kluczowy aspekt utrzymania wzajemnych, długoterminowych relacji i budowanie zaufania jako cel organizacji (Belanche Gracia i Casaló Ariño, 2015: 3), jest szczególnie ważne dla banku, dla którego kapitał relacyjny, jako składnik jego kapitału niefinansowego, powinien być otoczony szczególną troską. Zaufanie z dodanym przymiotnikiem ,publiczne” jest zatem wyższym poziomem zaufania 
- zawierzeniem (www1). Bank jako instytucja zaufania publicznego, narażona jest na ryzyko i zobligowana jest nim zarządzać. Gromadząc depozyty klientów nie powinna swoimi działaniami narażać ich na utratę środków pieniężnych. Kredytując klientów - powinna ich chronić przed pułapką zadłużeniową, a oferując produkty inwestycyjne - dostarczać rzetelnej informacji o ryzyku. Reasumując, nie może nadużywać pokładanego w niej zaufania, bowiem reputacja banku i zaufanie do niego to jego najważniejsze atrybuty. Powtarzając za D. Jurevičiené, V. Skvarciany, zaufanie zatem to pewność klienta, że menedżerowie podejmą wszelkie niezbędne działania z korzyścią dla klienta. Ważne przy tym jest, aby klient czuł się w banku komfortowo, będąc przekonanym o bezpieczeństwie jego relacji z bankiem, nie martwiąc się np. o utratę pieniędzy (Jurevičienè i Skvarciany, 2013: 533-534). Działalność banku jako instytucji zaufania publicznego powinna być zatem nierozerwalnie powiązana $\mathrm{z}$ dobrem klienta. Posiadane przez bank umiejętności, profesjonalna wiedza i przewaga informacyjna powinny służyć realizacji oraz ochronie zarówno własnych interesów, jak i jego interesariuszy. Jest to szczególnie ważne, ponieważ są oni słabszym ogniwem w relacji bank-klient, zwłaszcza, gdy są to konsumenci, wśród których spora grupa to seniorzy. Należy przy tym pamiętać, że jakość stosunków klienta $\mathrm{z}$ bankiem i jego doświadczenia $\mathrm{w}$ tym obszarze, przekładają się nie tylko na satysfakcję klienta, budującą zaufanie do banku, ale i na reputację banku, a szerzej sektora bankowego. Świadomość wagi i standardów działania banków dla samych banków jest zatem niezbędna dla ich dalszego rozwoju. W rzeczywistości jednak trudno jest spotkać się wyłącznie z wzorcowym podejściem banków do tego problemu. Wydaje się, że wystarczającym jest przytoczenie słów byłego prezesa BMO Capital Markets, E. Trippa. Stwierdził on, że banki popełniły zbyt wiele błędów, wystarczy przypomnieć chociażby niewłaściwe zarządzanie ryzykiem (Bear Stearns, Lehman Brothers i inne), konflikty interesów, złe osądy, nadmierną dźwignię, skandale, nie wspominając o samym kryzysie finansowym. Cenę za takie zachowania płaci cały sektor bankowy, i nie chodzi tylko o uratę zaufania, ale i kosztowne regulacje (Tripp, 2015).

Powołując się na raport z badania reputacji i zaufania do sektora bankowego w Polsce, przeprowadzonego w lutym 2020 roku, autorstwa M. Idzik i J. Gieorgica, reputacja banków na skali ogólnej okazała się dobra, przy czym banki oceniono najwyżej na tle innych branż (firmy ubezpieczeniowe, telekomunikacyjne, SKOK-i, firmy pożyczkowe). $51 \%$ Polaków oceniło reputację banków jako dobrą, bardzo dobrą, doskonałą. 18\% oceniło ją jako złą, bardzo złą lub skrajnie złą. Respondenci o niskim poziomie kompetencji ekonomicznej niżej oceniają reputację banków, podczas gdy respondenci o małej wiedzy ekonomicznej nie mają w tej kwestii sprecyzowanej opinii. Zaufanie do banków zadeklarowało $68 \%$ badanych (rok wcześniej 72\%), nieufność do banków - 23\% respondentów, 9\% nie miało 
zdania. Kwestia poczucia bezpieczeństwa była wskazywana jako główna przyczyna wzrostu, ale i spadku zaufania. Respondenci najpozytywniej ocenili nowoczesność banków, ich zaawansowanie technologiczne, dostępność usług. Więcej ocen negatywnych miały: uczciwość, wiarygodność banków, szacunek wobec klientów, etyka, społeczna odpowiedzialność (Idzik i Gieorgica, 2020: 121, 123$128,134)$.

Raport Gallupa z kolei wskazuje, że w 2019 roku zaufanie Amerykanów do banków utrzymało się na stabilnym poziomie, $30 \% \mathrm{z}$ nich miało duże/całkiem duże zaufanie do swoich banków, przy czym najwyższy poziom zaufania publicznego do banków był odnotowany w 2004 r. i wynosił wówczas 53\% (Gallup Poll: Americans' Confidence... 2019). Według badania z lipca 2020 roku zaufanie do banków w czasie pandemii wrosło - duże i całkiem duże zaufanie do banków zadeklarowało 38\% Amerykanów, zaś bardzo małe i brak zaufania zdeklarowało 19\% badanych (Brenan, 2020).

Warto również zaznaczyć, że L. Chernykh, D. Davydov i J. Sihvonen, stwierdzają, że zaufanie publiczne do banków jest bardzo wrażliwe na wskaźniki stabilności finansowej na poziomie sektora, mniej zaś na ryzyko na poziomie banku, co uwidacznia rangę stabilności sektora bankowego w publicznym postrzeganiu bezpieczeństwa banków (Chernykh, Davydov i Sihvonen, 2019). Nieprofesjonalni klienci banków często nie analizują sytuacji finansowej banku (wynika to z braku wiedzy na ten temat, niekiedy z braku czasu), zatem rzeczywiście duża ich część może postrzegać bezpieczeństwo banku raczej przez pryzmat bezpieczeństwa sektora jako całości, kierując się dodatkowo zasłyszanymi czy przeczytanymi opiniami na temat konkretnych banków.

Podejmując ważną kwestię determinantów zaufania do banków, można przytoczyć np. podejście prezentowane przez D. Jurevičienè, V. Skvarciany, klasyfikujące je w trzech grupach:

- czynniki warunkujące początkowy wybór banku (dostępne przed rozpoczęciem współpracy), m.in. wyniki finansowe, reputacja banku, konkurencyjność, nowoczesne technologie czy wielkość banku,

- czynniki zaufania wpływające na współpracę z bankiem (informacje otrzymywane w trakcie współpracy z bankiem), np. jakość usług, kompetencje i uprzejmość pracowników, oczekiwane wykorzystanie posiadanej wiedzy i umiejętności w relacjach z klientem czy jakość przekazywanych klientom informacji, także dotyczących podejmowanego ryzyka,

- czynniki determinujące budowę zaufania do banku, czyli satysfakcja klienta ze współpracy z bankiem, której poziom jest oceniany przez klienta na podstawie wniosków wyciąganych przed rozpoczęciem i w trakcie wzajemnej współpracy (Jurevičienè i Skvarciany, 2013: 534-537). Na poziom satysfakcji klienta mają przy tym wpływ kwestie uwypuklania przez bank oferowanej klientowi tzw. wartości dla 
klienta. Ważnym jest bowiem, aby klient nie pozostawał w mylnym przekonaniu, że wzajemna współpraca tworzy jedynie wartość dla banku.

V. Skvarciany i D. Jurevičienė prezentują również kryteria budujące zaufanie do popularnej wśród klientów bankowości internetowej, przekładające się na zaufanie do banku jako całości, dzieląc je na cztery grupy: informacja (jej transparentność, niezawodność, jakość); bank (m.in. kompetencje, goodwill, wspólne wartości, wizerunek banku); strona internetowa (bezpieczeństwo, przejrzystość/łatwość korzystania, prywatność); system bankowości elektronicznej (korzyści, motywacja, zadowolenie, uczciwość) (Skvarciany i Jurevičienè, 2018).

K.C. Lee oraz N. Chung, podejmujący z kolei tematykę czynników wpływających na zaufanie i satysfakcję w bankowości mobilnej w Korei, przywołują i analizują czynniki sukcesu (i ich współzależności) opracowane przez W.H. DeLone i E.R. McLean (autorów The IS success model). Są to: jakość systemu, jakość informacji, wykorzystanie systemu, satysfakcja użytkownika, czynnik indywidualny i czynnik organizacyjny oraz dodany w ramach późniejszej aktualizacji modelu dodatkowy czynnik - jakość usług. Na przywołany model składają się trzy wymiary - jakość systemu, jakość informacji i jakość usług (Lee i Chung, 2009: 385-392).

Jak wynika z przeprowadzonych wywodów, jednym z ważniejszych czynników wpływających na stopień zaufania do banków, obok czynników o charakterze typowo wymiernym (wartość współpracy dla klienta, bezpieczeństwo), jest czynnik nieekonomiczny - jakość, kompletność, terminowość, rzetelność przekazywanych klientom informacji, zarówno na temat oferty, jak i korzyści dla klienta, czynników ryzyka, kondycji banku. Wiarygodności informacyjnej banku i jej randze dla seniorów, jako licznej rzeszy klientów banków, zostaną poświęcone kolejne punkty niniejszego artykułu.

Niewątpliwie zaufanie klientów do banków wzmacnia istnienie państwowych gwarancji zaufania publicznego. E. Radziszewski wymienia wśród nich gwarancje prawne oraz instytucjonalne, dodając jednocześnie, że w praktyce funkcjonują one jednocześnie, wzajemnie się przeplatając, co uzasadnia ich wspólne ujmowanie (Radziszewski, 2013: 13). Wybrane gwarancje zaprezentowano w tabeli 1. 
Tabela 1. Wybrane gwarancje prawne/instytucjonalne zaufania publicznego do banków

\begin{tabular}{|c|c|}
\hline $\begin{array}{l}\text { Gwarancje prawne/instytucjonalne zaufania } \\
\text { publicznego do banków - Polska }\end{array}$ & $\begin{array}{c}\text { Gwarancje prawne/instytucjonalne zaufania } \\
\text { publicznego do banków - szczebel Unii } \\
\text { Europejskiej }\end{array}$ \\
\hline $\begin{array}{l}\text { Regulacje prawne, m.in. Konstytucja, ustawa } \\
\text { Prawo bankowe, ustawa o NBP, ustawa o funk- } \\
\text { cjonowaniu banków spółdzielczych, ich zrze- } \\
\text { szaniu i się i bankach zrzeszających, ustawa } \\
\text { o listach zastawnych i bankach hipotecznych, } \\
\text { ustawa o nadzorze nad rynkiem finansowym, } \\
\text { ustawa o Bankowym Funduszu Gwarancyj- } \\
\text { nym, systemie gwarantowania depozytów oraz } \\
\text { przymusowej restrukturyzacji, ustawa o kredy- } \\
\text { cie konsumenckim, ustawa o usługach płatni- } \\
\text { czych, obowiązujące bezpośrednio w każdym } \\
\text { kraju rozporządzenie CRR i inne akty prawne } \\
\text { najwyższej rangi oraz niższego rzędu, uchwały } \\
\text { i rekomendacje nadzorcze. }\end{array}$ & $\begin{array}{l}\text { Regulacje prawne, m.in. dyrektywa CRD IV } \\
\text { i rozporządzenie CRR (ze zmianami), dyrek- } \\
\text { tywa w sprawie dodatkowego nadzoru nad in- } \\
\text { stytucjami kredytowymi, zakładami ubezpie- } \\
\text { czeń oraz przedsiębiorstwami inwestycyjnymi } \\
\text { konglomeratu finansowego, dyrektywa w spra- } \\
\text { wie systemów gwarancji depozytów, dyrek- } \\
\text { tywa w sprawie umów o kredyt konsumencki, } \\
\text { dyrektywa ustanawiająca ramy na potrzeby } \\
\text { prowadzenia działań naprawczych oraz re- } \\
\text { strukturyzacji i uporządkowanej likwidacji } \\
\text { w odniesieniu do instytucji kredytowych i firm } \\
\text { inwestycyjnych, dyrektywa PSD2. }\end{array}$ \\
\hline $\begin{array}{l}\text { Licencjonowanie dzialalności banków - ko- } \\
\text { nieczność uzyskania zezwolenia Komisji Nad- } \\
\text { zoru Finansowego na utworzenie banku oraz } \\
\text { zezwolenia na rozpoczęcia działalności banku, } \\
\text { nadzór nad ich działalnością i sankcjonowanie. }\end{array}$ & $\begin{array}{l}\text { Licencjonowanie dzialalności banków - dy- } \\
\text { rektywa CRD IV: państwa członkowskie wy- } \\
\text { magają uzyskania przez instytucje kredytowe } \\
\text { zezwolenia przed rozpoczęciem działalności, } \\
\text { państwa określają warunki uzyskiwania ze- } \\
\text { zwoleń i powiadamiają o nich EUNB. }\end{array}$ \\
\hline $\begin{array}{l}\text { Zastrzeżenie nazwy „bank” i działalności - } \\
\text { Wyrazy „bank” lub „kasa” mogą być używane } \\
\text { w nazwie oraz dla określenia działalności lub } \\
\text { reklamy wyłącznie banku w rozumieniu art. } 2 \\
\text { ustawy Prawo bankowe (zawierającego usta- } \\
\text { wową definicję banku). } \\
\text { Ustawowo wskazany katalog czynności ban- } \\
\text { kowych, w tym czynności zastrzeżonych do } \\
\text { wyłącznej kompetencji banków (czynności } \\
\text { stricte bankowe). }\end{array}$ & $\begin{array}{l}\text { Zastrzeżenie nazwy „bank” - instytucje kre- } \\
\text { dytowe mogą używać na całym obszarze Unii } \\
\text { tej samej nazwy, jakiej używają w państwie } \\
\text { członkowskim, w którym posiadają siedzibę } \\
\text { zarządu, niezależnie od przepisów, które mogą } \\
\text { obowiązywać w przyjmującym państwie } \\
\text { członkowskim, dotyczących używania okre- } \\
\text { śleń „bank”, „,bank oszczędnościowy” lub in- } \\
\text { nych nazw dotyczących bankowości” (Dyrek- } \\
\text { tywa CRD IV). }\end{array}$ \\
\hline $\begin{array}{l}\text { Obowiązek zarządzania ryzykiem i prze- } \\
\text { strzegania norm adekwatności kapitalowej } \\
\text { i plynnościowej - m.in. Ustawa Prawo Ban- } \\
\text { kowe + akty wykonawcze, ustawa o nadzorze } \\
\text { makroostrożnościowym nad systemem finan- } \\
\text { sowym i zarządzaniu kryzysowym w systemie } \\
\text { finansowym, CRR (zmiany z } 2019 \text { roku - } \\
\text { CRR II). }\end{array}$ & $\begin{array}{l}\text { Obowiązek zarządzania ryzykiem i prze- } \\
\text { strzegania norm adekwatności kapitałowej } \\
\text { i płynnościowej - przede wszystkim pakiet } \\
\text { CRD IV/CRR (zmiany z } 2019 \text { roku: } \\
\text { CRD V/CRR II). }\end{array}$ \\
\hline $\begin{array}{l}\text { Obowiązki banków w zakresie ujawnień - } \\
\text { Ustawa Prawo Bankowe (art. 111a, p.4), CRR. }\end{array}$ & $\begin{array}{l}\text { Obowiązki banków w zakresie ujawnień - } \\
\text { Rozporządzenie Parlamentu Europejskiego } \\
\text { i Rady (UE) nr 575/2013 (CRR). }\end{array}$ \\
\hline
\end{tabular}




\begin{tabular}{|c|c|}
\hline $\begin{array}{l}\text { Instytucja tajemnicy bankowej (obecnie co- } \\
\text { raz bardziej iluzoryczna) - ustawa Prawo ban- } \\
\text { kowe. Uwaga na obowiązki informacyjne wy- } \\
\text { nikające z ustawy FATCA (Foreign Account } \\
\text { Tax Campliance Act) oraz unijnej Euro- } \\
\text { FATCA (dyrektywa w sprawie obowiązkowej } \\
\text { automatycznej wymiany informacji w dziedzi- } \\
\text { nie opodatkowania, dyrektywa implemento- } \\
\text { wana ustawą o wymianie informacji podatko- } \\
\text { wych). }\end{array}$ & $\begin{array}{l}\text { Tajemnica zawodowa lub służbowa, wy- } \\
\text { miana, ujawnianie informacji - Dyrektywa } \\
\text { 2013/36/UE (CRD IV). }\end{array}$ \\
\hline $\begin{array}{l}\text { Siatka bezpieczeństwa finansowego: } \\
\text { - Komisja Nadzoru Finansowego (KNF) - } \\
\text { nadzór mikrostrożnościowy } \\
\text { - Komitet Stabilności Finansowej (KSF) - } \\
\text { nadzór makroostrożnościowy } \\
\text { - Bankowy Fundusz Gwarancyjny (BG) -wy- } \\
\text { płata sum gwarantowanych, krajowy } \\
\text { organ resolution } \\
\text { - Bank Centralny (polityka pieniężna, } \\
\text { pożyczkodawca ostatniej szansy...) } \\
\text { - Rząd (pomoc publiczna, regulacje) }\end{array}$ & $\begin{array}{l}\text { Siatka bezpieczeństwa finansowego: } \\
\text { - Europejski Urząd Nadzoru Bankowego - } \\
\text { nadzór mikroostrożnościowy } \\
\text { - Europejska Rada ds. Ryzyka Systemowego: } \\
\text { nadzór makroostrożnościowy } \\
\text { - EBC - nadzór zintegrowany, mikro i makro- } \\
\text { ostrożnosciowy (Rada ds. Nadzoru) } \\
\text { - Organy resolution: EBC, Europejska Rada } \\
\text { ds. Restrukturyzacji i Uporządkowanej } \\
\text { Likwidacji banków, Komisja Europejska, } \\
\text { Fundusz Resolution } \\
\text { - EBC - polityka pieniężna eurosystemu } \\
\text { (Rada Prezesów) } \\
\text { - Komisja Europejska - komisarze odpowia- } \\
\text { dający randze ministrów w rządach poszcze- } \\
\text { gólnych państw (np. legislacja, zarządzanie } \\
\text { funduszami). }\end{array}$ \\
\hline
\end{tabular}

Źródło: opracowanie własne na podstawie: Radziszewski, 2013; Hornowska, 2019: 37,38; Ustawa z 29.08.1997 r. Prawo Bankowe (tj. Dz.U. 2020, poz. 1896, 2320, 2419); Directive 2013/36/EU of the European Parliament and of the Council of 26 June 2013 on access to the activity of credit institutions and the prudential supervision of credit institutions and investment firms, amending Directive 2002/87/EC and repealing Directives 2006/48/EC and 2006/49/EC (OJ L 176/338, 27.6.2013); Directive (EU) No 2019/878 of the European Parliament and of the Council of 20 may 2019 amending directive 2013/36/EU as regards exempted entities, financial holding companies, mixed financial holding companies, remuneration, supervisory measures and powers and capital conservation measures (OJ L 150/253, 7.6.2019); Regulation (EU) No 575/2013 of the European Parliament and of the Council of 26 June 2013 on prudential requirements for credit institutions and investment firms and amending Regulation (EU) No 648/2012 (OJ L 176, 27.6.2013); Regulation (EU) 2019/876 of the European Parliament and of the Council of 20 May 2019 amending Regulation (EU) No 575/2013 as regards the leverage ratio, the net stable funding ratio, requirements for own funds and eligible liabilities, counterparty credit risk, market risk, exposures to central counterparties, exposures to collective investment undertakings, large exposures, reporting and disclosure requirements, and Regulation (EU) No 648/2012 (OJ L 150.1, 7.6.2019). 


\section{PRZEWAGA INFORMACYJNA BANKU - PROBLEM NIEKORZYSTNEGO DLA KLIENTA PRZEKAZU INFORMACJI I (NIE)ADEKWATNOŚCI DOBORU PROPONOWANYCH PRODUKTÓW (MISSELLING)}

Informacja jest w dzisiejszych czasach jednym z najistotniejszych zasobów, jakie podmioty na rynku wykorzystują we wzajemnych relacjach. Jest to szczególnie ważne na rynku finansowym, albowiem ze względu na jego specyfikę, można spotkać się ze zjawiskiem asymetrii informacji, tj. sytuacji, w której jedna ze stron umowy posiada więcej informacji na jej temat, aniżeli druga. K. Raczkowski i A. Markiewicz podkreślają, że ,(...) najpoważniejszą grupę zniekształceń stanowią te świadome, które w sposób przemyślany mają na celu wprowadzenie klienta w błąd. Świadome wywoływanie zniekształceń jest manipulacją, która w obiegowej opinii jest najczęściej narzędziem w ręku profesjonalnego uczestnika rynku finansowego, wykorzystywanym przeciw słabszemu uczestnikowi, jakim jest konsument (...)” (Raczkowski i Markiewicz, 2015: 148). Podkreśla się także, że na rynku usług finansowych, uprzywilejowanej pozycji banku sprzyja przede wszystkim fakt, iż bank jest traktowany jako instytucja zaufania publicznego, a co za tym idzie klient może przyjmować założenie, że bank postępuje wobec niego uczciwie. Nie bez znaczenia pozostaje również lepsza znajomość przepisów prawa po stronie banku oraz umiejętność korzystania z fachowego słownictwa. Z drugiej jednak strony, klient w pewnych sytuacjach także może znajdować się na uprzywilejowanej pozycji w relacjach z bankiem. Zna on bowiem najlepiej swoją sytuację finansową i nie zawsze będzie skłonny ujawniać wszystkie posiadane przez siebie informacje. W takiej sytuacji bank będzie opierać się na informacji dostępnej w zewnętrznych bazach danych, co jednak rodzi ryzyko braku dostępu do pełnej informacji, a także koszty finansowe po stronie banku. O. Stolper zauważa także, że widoczne jest, iż klienci indywidualni stale zwiększają swój poziom świadomości finansowej, ale jednocześnie korzystając z usług na rynku finansowym, stają przed problemem złożoności produktów i usług, które są na nim dostępne (Stolper, 2018: 295). Trudności w przejrzystości wynikają z rozwoju produktów i mogą pojawić się przed podjęciem decyzji o zakupie (Ostrowska-Dankiewicz, 2019: 171).

Praktyka pokazuje jednak, że banki stosunkowo chętnie wykorzystują swoją przewagę wobec klienta. Jest to efektem wysokiego poziomu złożoności usług finansowych, co może skutkować zawarciem przez klienta niekorzystnej (lub nawet naruszającej jego interesy) umowy. Podkreślić tu trzeba, że klient nie zawsze ma wystarczającą wiedzę, która pozwoli mu zrozumieć istotę skomplikowanego produktu (Jakubowska, 2017: 128-129). W tabeli 2 przedstawione zostały podstawy relacji pomiędzy bankiem a klientem w kontekście asymetrii informacyjnej. 
Tabela 2. Relacje na linii bank-klient

\begin{tabular}{|l|l|}
\hline \multicolumn{1}{|c|}{ Ujęcie teoretyczne } & \multicolumn{1}{c|}{ Ujęcie praktyczne } \\
\hline Strony powinny być równe wobec prawa & Przewaga prawna banku \\
\hline Strony powinny być wobec siebie uczciwe & Ostrożność względem klienta \\
\hline Symetria informacji & Asymetria informacji \\
\hline Podział ryzyka między bank a klienta & Przerzucanie ryzyka na klienta \\
\hline Swoboda zawierania umów & Wymuszanie na kliencie podpisania umowy \\
\hline
\end{tabular}

Źródło: Jakubowska, 2017: 129.

W tym kontekście istotne wydają się być wyniki badań przeprowadzonych przez KPMG w 2019 r., które pokazały, że konsumenci oceniają swoje doświadczenia z branżą finansową gorzej, niż w przypadku innych branż. Ogólna ocena sektora bankowego była pochodną m.in. doświadczeń konsumentów z takimi produktami jak polisolokaty $i$ kredyty hipoteczne udzielane we frankach szwajcarskich, jak również agresywnymi kampaniami banków, związanymi z oferowanymi przez siebie produktami. Na taki stan rzeczy ma również wpływ fakt, że sektor bankowy jest przez konsumentów traktowany jako element infrastruktury usługowej, niezbędnej do zaspokajania określonych potrzeb, a relacja z bankiem ma raczej długookresowy charakter, w związku z czym brakuje w niej momentów „ekscytacji”. Znamienny natomiast pozostaje fakt, że wskaźnik $\mathrm{CEE}^{1}$ dla sektora bankowego wzrósł w porównaniu do badań przeprowadzonych w 2018 r. (KPMG 2019).

Przykładem nieetycznych postaw banków wobec klienta jest misselling. Jest on różnie definiowany w literaturze. J. Cichorska zauważa, że zjawisko to wykształciło się jako efekt nieuczciwych praktyk stosowanych przez instytucje finansowe (Cichorska, 2017: 19). G. Franke, T. Mosk i E. Schnebel proponują natomiast, żeby wyróżnić pewne istotne cechy missellingu, tj. błędne przedstawienie informacji, złożoną strukturę produktu oraz niedostatecznie spersonalizowane doradztwo (Franke, Mosk i Schnebel, 2016: 4). Przez pojęcie to rozumie się przede wszystkim sprzedaż produktów, które nie są dostosowane do potrzeb klientów, jak również takie zachowania instytucji finansowych, które wprowadzają klienta w błąd. Obowiązująca od 2016 r. znowelizowana ustawa o ochronie konkurencji i konsumenta wprowadziła zakaz missellingu, jako praktyki, która narusza interesy konsumentów. Na fakt ten zwraca uwagę J. Orlicka, wskazując, iż niezgodne z przepisami prawa jest ,(...) proponowanie konsumentom nabycia usług finansowych, które nie odpowiadają potrzebom tych konsumentów ustalonym $\mathrm{z}$ uwzględnieniem dostępnych przedsiębiorcy informacji $\mathrm{w}$ zakresie cech tych

${ }^{1}$ CEE - syntetyczny wskaźnik, pokazujący skłonność konsumenta do rekomendacji marki. Bazuje on na sześciu filarach, tj. rozwiązywanie problemów, wiarygodność, oczekiwania, czas i wysiłek, empatia, personalizacja. 
konsumentów lub proponowanie nabycia tych usług w sposób nieadekwatny do ich charakteru (...)" (Orlicka, 2015: 42). M. Paduszyńska podkreśla natomiast, że usługi finansowe, których dotyczy misselling, charakteryzuje niska przydatność. Ponadto, połączenie niskiej wiedzy konsumenta i braku kompetencji po stronie sprzedawcy, skutkuje poważną utratą zaufania i prowadzi do zjawiska missellingu. Przedsiębiorcy, powinni dbać o to, żeby konsument mógł podejmować świadome decyzje. Informacja, którą mu przekazują powinna być jasna i przekazywana możliwie prostym językiem (Paduszyńska 2019: 50).

W tym kontekście, bardzo ważnym problemem staje się włączenie finansowe osób starszych. Z danych i prognoz demograficznych wynika bowiem, że udział osób starszych w ogóle społeczeństwa stale się zwiększa i w związku z tym należy propagować tzw. aktywne starzenie się. Ważne jest więc, aby prowadzić kampanie zachęcające do korzystania z usług bankowych, z drugiej zaś strony zwiększać wiedzę finansową i przekonanie o bezpieczeństwie korzystania z tych usług. Wykluczenie finansowe $\mathrm{w}$ tej grupie jest bowiem pogłębiane przez brak przekonania co do bezpieczeństwa konsumenta na rynku usług bankowych. Seniorzy często wykazują dużą niechęć do banków lub nie wiedzą w jaki sposób korzystać z produktów bankowych, w tym nawet tych prostych, jak konto bankowe czy karta płatnicza. Problemem nierzadko jest także specjalistyczny język, w jakim są konstruowane umowy bankowe, co dodatkowo zwiększa awersję do korzystania z usług banku (Rzecznik Praw Obywatelskich, 2013).

\section{WIARYGODNOŚĆ INFORMACYJNA BANKU W OCENIE SENIORÓW KORZYSTAJĄCYCH Z USEUG BANKOWYCH}

W celu weryfikacji teoretycznych rozważań skupiających się na problemie wiarygodności informacyjnej, Autorzy artykułu przeprowadzili badanie ankietowe mające na celu ocenę tego problemu w grupie seniorów. Badanie zostało przeprowadzone wśród uczestników Uniwersytetu Trzeciego Wieku, prowadzonego na Uniwersytecie Ekonomicznym w Katowicach. Grupa ankietowanych została wybrana nieprzypadkowo, Autorzy przyjęli bowiem założenie, że uczestnicy tego programu wykazują się większą niż średnia wiedzą ekonomiczną (świadczyć może o tym relatywnie wysoki udział ankietowanych legitymujących się wyższym wykształceniem - 52,4\%), są aktywnymi uczestnikami życia gospodarczego i w większości korzystają z usług bankowych. Badanie ankietowe zostało przeprowadzone w lutym $2021 \mathrm{r}$. i wzięło w nim udział $85 \mathrm{osób}^{2}$. Wstępem do badania był krótki wykład, na którym przedstawiono istotę wiarygodności informacyjnej, a także omówiono istotę ankiety i jej konstrukcję.

${ }^{2}$ Struktura ankietowanych: płeć: kobieta $-67,9 \%$, mężczyzna $-32,1 \%$; wiek: $55-60$ lat $13,3 \%, 61-65$ lat $-18,1 \%, 66-71$ lat $-41 \%,>71$ lat $-27,7 \%$; wykształcenie: podstawowe $-1,2 \%$, zawodowe $-15,5 \%$, średnie $-31 \%$, wyższe $-52,4 \%$. 
Podkreślić należy, że ankietowani wykazują się dużym zróżnicowaniem w kwestii produktów bankowych, z jakich korzystają. Najwięcej osób korzysta $\mathrm{z}$ rachunku oszczędnościowo-rozliczeniowego $(95,2 \%$ ankietowanych) oraz karty płatniczej $(77,4 \%)$, nieco mniej z nich korzysta z kredytów $(32,1 \%)$, najmniejszym zainteresowaniem cieszą się produkty inwestycyjne (26,2\%), choć odsetek ten i tak wydaje się być relatywnie wysoki (wykres 1).

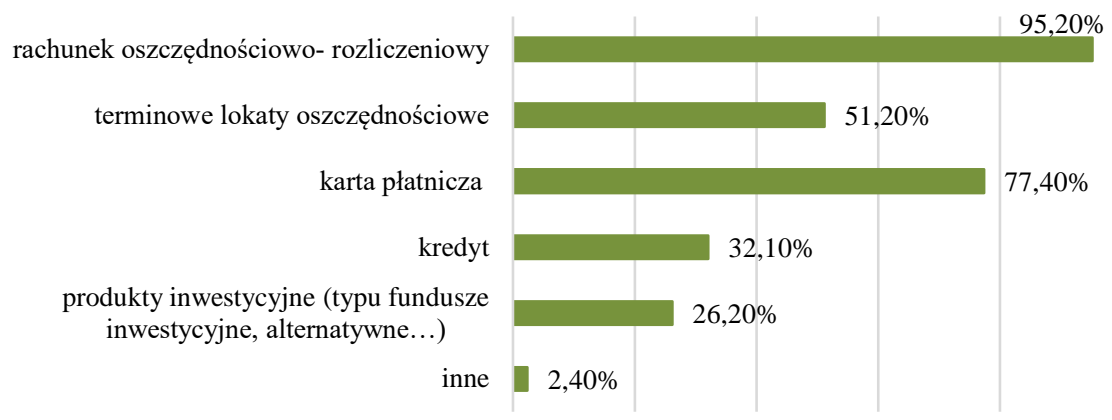

Wykres 1. Z jakich usług bankowych Pan/Pani korzysta (jako odsetek udzielonych odpowiedzi)

Źródło: opracowanie własne.

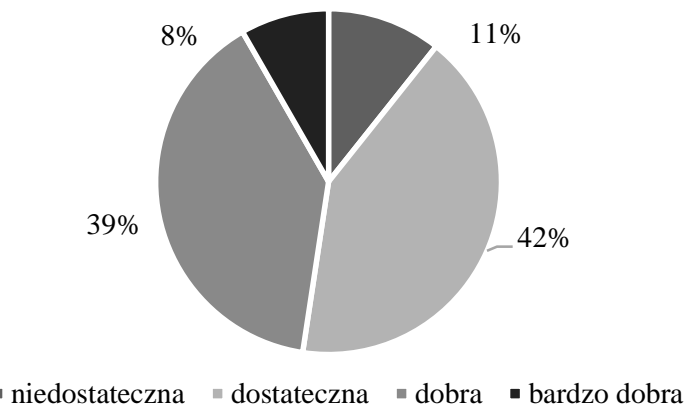

Wykres 2. Jak ocenia Pan/Pani swoją wiedzę bankową, zwłaszcza dotyczącą oszczędzania, inwestowania, kredytu (jako odsetek ankietowanych)

Źródło: opracowanie własne.

Ponadto, większość ankietowanych korzysta $\mathrm{z}$ bankowości internetowej $(47,6 \%)$. Jest to znamienne, bo pokazuje, że w grupie seniorów stopień wykorzystania współczesnych kanałów kontaktu z bankiem można uznać za wysoki. Wysoka jest nadal popularność tradycyjnej obsługi w oddziale (41,7\%). Ankietowani w małym stopniu korzystają natomiast $\mathrm{z}$ aplikacji mobilnych $(7,1 \%)$ oraz call- 
center (jedynie 3,6\%). Wśród ankietowanych dominuje także przekonanie o dobrym poziomie wiedzy na temat produktów bankowych (42\%). Niemniej jednak, warto zwrócić uwagę na fakt, że aż $11 \%$ ankietowanych ocena swój poziom wiedzy jako niedostateczny (wykres 2).

Dokonując oceny wiarygodności informacyjnej banku, 39,3\% ankietowanych wskazało, że przekaz informacyjny banku jest dla nich czytelny oraz pełny, a bank w sposób właściwy informuje ich o podejmowanym ryzyku. Istotnym jest natomiast fakt, że aż 26,2\% ankietowanych nie jest w stanie ocenić tej kwestii (wykres 3). Może to wynikać z faktu, iż klienci banku nie zadają, bądź nie wiedzą jakie pytania trzeba zadać, aby zwiększyć swoją wiedzę na temat danego produktu, a tym samym przyjmują jedynie do wiadomości te informacje, które przekazuje im pracownik banku. Ponadto $57,1 \%$ ankietowanych weryfikuje informacje otrzymane od banku. Najczęściej dodatkowe informacje pozyskują oni w Internecie, od znajomych oraz rodziny. Powstaje tu więc potrzeba weryfikacji otrzymanych informacji, a źródła pozyskania wiedzy są relatywnie zróżnicowane. Trzeba jednak dodać, że ankietowani ufają przede wszystkim tym osobom, które znają. Rzadziej zwracają się do wykwalifikowanych doradców finansowych.

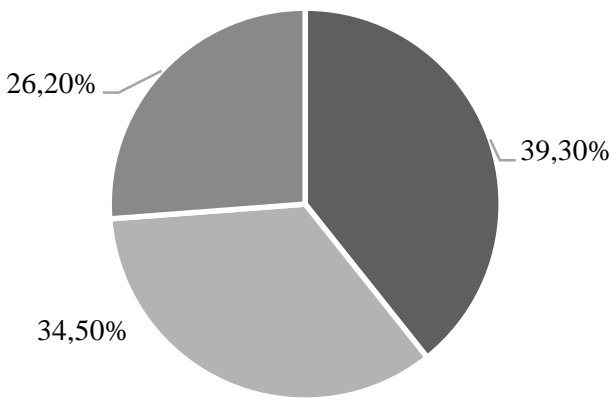

\footnotetext{
- jest dla mnie zrozumiały i wiarygodny i wg mnie pełny. Bank informuje mnie o podejmowanym ryzyku w oczekiwanym zakresie

- oczekiwałbym szerszych informacji dotyczących produktów, zasad korzystania z nich i ryzyka, jakie jest z nimi związane

- nie potrafię tego ocenić
}

Wykres 3. Jak ocenia Pan/Pani przekaz informacji na linii Pana/Pani bank - Pan/Pani jako klient (wiarygodność informacyjną banku) (jako odsetek ankietowanych)

Źródło: opracowanie własne. 
$75 \%$ ankietowanych wskazało również, iż zdarzyło się, że bank udzielił im niepełnych, a nawet wprowadzających w błąd informacji. Jako przykład takiego zdarzenia, ankietowani podawali m.in. potrącenie wyższej kwoty za obsługę rachunku i karty płatniczej, sprzedaż polisy, która w założeniu miała być standardową lokatą, zakup akcji rynków wschodzących, czego efektem była duża strata finansowa, czy wysokie koszty obsługi funduszy inwestycyjnych. Przykłady podawane przez ankietowanych odnoszą się do szerokiej gamy produktów bankowych, a sam fakt, iż większość ankietowanych wskazała konkretne przykłady takich sytuacji, może wskazywać, że z jednej strony banki celowo nie informują swoich klientów o istotnych dla nich kwestiach, z drugiej zaś, że klienci posiadają zbyt mały poziom wiedzy finansowej i trudno jest im odnaleźć się w dużej ilości regulacji i zapisów umownych.

$26,2 \%$ ankietowanych wskazało natomiast, że padło ofiarą missellingu. $41,7 \%$ wskazało, że nie doświadczyło tego problemu, $32,1 \%$ nie było natomiast pewnych, czy było ofiarą takiego zjawiska (wykres 4). Wśród sytuacji, w jakich ten problem się zmaterializował, ankietowani wskazali przede wszystkim oferowanie przez bank takich produktów, które klient uznał za zbędne, nieadekwatne do jego potrzeb. Wśród nich wymieniono m.in. fundusze inwestycyjne, karty kredytowe, ubezpieczenie na życie, konta oszczędnościowe. Ankietowani, którzy zetknęli się z tym zjawiskiem wskazali ponadto, że ma ono charakter niezwykle częsty (większość ankietowanych szczegółowo opisywała konkretne przypadki w pytaniu otwartym).

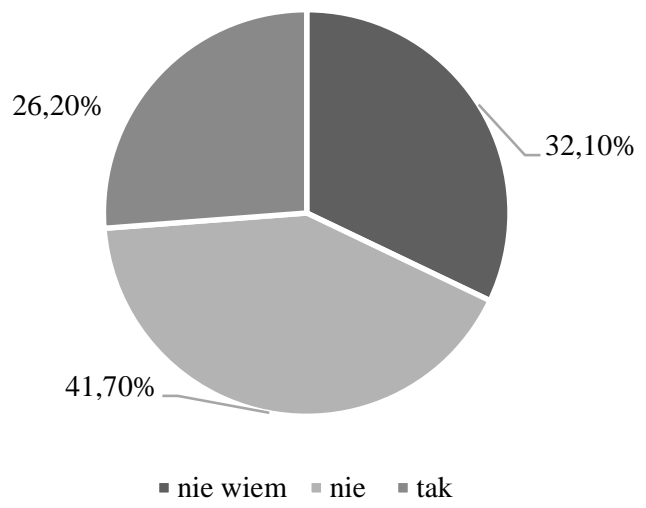

Wykres 4. Czy kiedykolwiek był Pan/ Pani ofiarą missellingu - czyli czy proponowano Panu/Pani zbędne produkty, nieadekwatne do Pana/Pani potrzeb, kierując się interesem banku, a nie klienta

Źródło: opracowanie własne. 
Kolejne pytania zadane ankietowanym miały na celu ocenę ich szeroko rozumianego zaufania do banków. 69,9\% ankietowanych wskazało, że zaufanie do banków przekłada się na jego wiarygodność informacyjną (21,7\% ankietowanych nie ma zdania w tej kwestii, podczas gdy dla 8,4\% taki związek nie występuje) wykres 5 . Ponadto, jedynie $25 \%$ zna dobrze prawne gwarancje zaufania do sektora bankowe (np. istnienie tajemnicy bankowej, ochronę deponenta, fakt istnienia nadzoru nad sektorem bankowym), 56\% zna je częściowo. Niestety, aż 19\% ankietowanych nie ma świadomości ich istnienia.

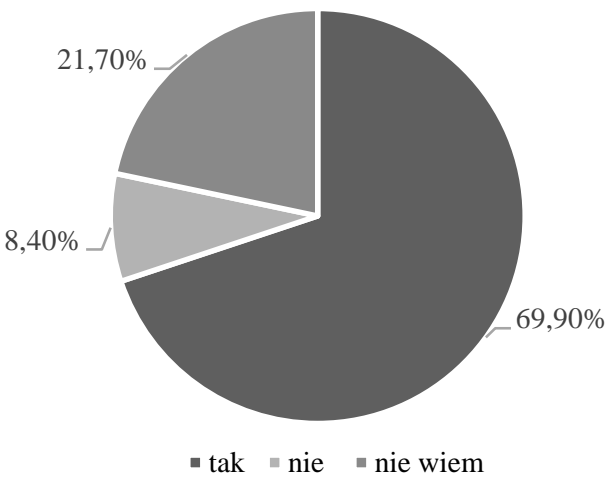

Wykres 5. Czy zaufanie do banku przekłada Pan/Pani na jego wiarygodność informacyjną?

Źródło: opracowanie własne.

$52 \%$ ankietowanych, którzy mają świadomość istnienia takich gwarancji uważa, że są one ważne w kontekście znaczenia dla zaufania do banku. 15,7\% ankietowanych uważa, że nie mają one znaczenia, podczas gdy aż 31,3\% ankietowanych nie ma zdania w tej kwestii.

Wyniki przeprowadzonego badania pokazały, że w badanej grupie seniorów dominuje przekonanie o zaniedbaniach niektórych banków w zakresie jakości informacji przekazywanej klientom. $Z$ drugiej strony należy podkreślić, że ponad połowa ankietowanych weryfikuje informacje otrzymane $\mathrm{z}$ banku, co niewątpliwie świadczy o chęci pogłębienia swojej wiedzy dotyczącej danego produktu, $\mathrm{z}$ drugiej zaś o pewnej nieufności do doradców bankowych. Znamiennym pozostaje również fakt, że zdecydowana większość ankietowanych uznaje wiarygodność informacyjną za istotny czynnik wpływający na poziom zaufania do banku. Ważna jest tu także świadomość istnienia prawnych gwarancji zaufania do banków. Wydaje się, że w tym obszarze duże znaczenia ma także edukacja finansowa, która pozwoli zwiększyć świadomość istnienia tych gwarancji oraz mechanizmów ich funkcjonowania. 


\section{PODSUMOWANIE}

Na zaufanie do banku wpływa wiele różnorodnych czynników. Wśród nich można wymienić te o charakterze ekonomicznym (wymiernym), jak i te, mające charakter jakościowy. W grupie seniorów istotne znaczenie Autorzy artykułu przypisują wiarygodności informacyjnej banku. W ocenie banku przez ich klientów bardzo ważny pozostaje aspekt ich etycznego postępowania, co materializuje się m.in. poprzez jakość informacji i sposób jej przekazywania. Kwestie te składają się właśnie na wiarygodność informacyjną. Badanie ankietowe, przeprowadzone w grupie seniorów, pozwoliło pokazać, że dla tej grupy klientów właściwa relacja z bankiem ma kluczowe znaczenie. Zdecydowana większość ankietowanych zwróciła uwagę na problem niepełnych informacji, bądź informacji celowo wprowadzających $\mathrm{w}$ błąd. Wskazali oni także, jakich dotyczyło to produktów. 69\% ankietowanych wskazało wprost, że zaufanie do banku jest konsekwencją jego wiarygodności informacyjnej. Można uznać, że jest ona istotnym czynnikiem, który wpływa na ocenę banku przez seniorów, co potwierdza postawioną przez Autorów hipotezę.

Autorzy artykułu pragną podkreślić, że wybór badanej grupy oraz dobór ankietowanych był celowy. Seniorzy stanowią bowiem bardzo dużą grupę społeczną, która wykazuje tendencję do znaczącego zróżnicowania pod względem różnych cech, m.in. wieku, wykształcenia, poziomu specjalistycznej wiedzy ekonomicznej, czy szeroko rozumianego podejścia do kwestii finansowych (w tym korzystania z usług banków). Przeprowadzenie badania wśród osób, będących uczestnikami Uniwersytetu Trzeciego Wieku, pozwoliło pokazać, w jaki sposób do kwestii wiarygodności informacyjnej banku podchodzi specyficzna grupa seniorów, tj. osób aktywnych, świadomych ekonomicznie oraz chcących przez całe życie podnosić swoją wiedzę i rozwijać swoje zainteresowania.

Podsumowując, należy zauważyć, że tak przeprowadzone badanie ma swoje ograniczenia. Wynikają one przede wszystkim z liczebności grupy badawczej oraz jej specyfiki. W związku z tym Autorzy planują przeprowadzenie badania na większej grupie badawczej i zaangażowanie do współpracy przy jego realizacji m.in. tych instytucji, które w obszarze swojej działalności mają szeroko rozumiane działania na rzecz osób starszych oraz w dużym stopniu rozumieją specyfikę tej grupy społecznej. W ocenie Autorów może to przyczynić się do wypracowania dobrych praktyk w tym obszarze. 


\section{BIBLIOGRAFIA:}

Belanche Gracia, D. and Casaló Ariño, L.V. (2015). Rebuilding public trust in government admini-strations through e-government actions. Revista Española de Investigación de Marketing ESIC, 19, https://reader.elsevier.com/reader/sd/pii/S1138144214000072?token=F78646F2761078832C5213B7A28A8F2F51CB42447C0ADF1520208CB26FEE19DB 8F84FC6A09AF7B63402038A23DE9D4C5 (dostęp 10.01.2021).

Brenan, M. (2020). Amid Pandemic, Confidence in Key U.S. Institutions Surges. Politics, August 12, https://news.gallup.com/poll/317135/amid-pandemic-confidence-key-institutions-surges.aspx (dostęp 27.01.2021).

Cichorska, J. (2017). Misselling, czyli sprzedaż niepotrzebnych instrumentów finansowych i jej skutki. Stan prawny w Polsce i Wielkiej Brytanii. Rozprawy ubezpieczeniowe. Konsument na rynku ustug finansowych, 24 (2), https://rf.gov.pl/ru/wp-content/uploads/2017/08/RU24_2.pdf (dostęp 15.02.2021).

Chernykh, L., Davydov D. and Sihvonen J. (2019). Financial Stability and Public Confidence in Banks. BOFIT Discussion Paper, 2, https://papers.ssrn.com/sol3/papers.cfm?abstract_id=3339743 (dostęp 26.01.2021).

Chryssochoidis, G., Strada, A. and Krystalli, A. (2009). Public trust in institutions and information sources regarding risk management and communication: Towards integrating extant knowledge. Journal of Risk Research, 12(2).

Directive (EU) No 2019/878 of the European Parliament and of the Council of 20 may 2019 amending directive 2013/36/EU as regards exempted entities, financial holding companies, mixed financial holding companies, remuneration, supervisory measures and powers and capital conservation measures, OJ L 150/253, 7.6.2019.

Directive 2013/36/EU of the European Parliament and of the Council of 26 June 2013 on access to the activity of credit institutions and the prudential supervision of credit institutions and investment firms, amending Directive 2002/87/EC and repealing Directives 2006/48/EC and 2006/49/EC, OJ L 176/338, 27.6.2013.

Franke, G., Mosk, T. and Schnebel, E. (2016). Fair Retail Banking: How to Prevent Misselling by Banks? White Paper, 39, https://safe-frankfurt.de/fileadmin/user_upload/editor_common/Policy_Center/Franke-Mosk-Schnebel-Fair_Retail_Banking.pdf (dostęp 09.03.2021).

Gallup Poll: Americans' Confidence in Banks Holds Steady, on 10.07.2019, https://bankingjournal.aba.com/2019/07/gallup-poll-americans-confidence-in-banks-holds-steady/\# (dostęp 27.01.2021).

Hornowska, A. (2019). Tajemnica bankowa - konstrukcja, przesłanki, procedura ochrony i zwolnienia - ujęcie komparatystyczne. Prawo karne i kryminologia. Warszawa: Instytut Wymiaru Sprawiedliwości.

Hurley, R.F. (2006). The Decision to Trust - from the Magazine, https://hbr.org/2006/09/the-decision-to-trust (dostęp 14.01.2021).

Idzik, M. and Gieorgica, J. (2020). Reputacja sektora bankowego 2020 - kluczowe wyniki i wnioski $\mathrm{z}$ badania (Reputation of the Bankig Sector in 2020 - Key Results and Conclusions). Bezpieczny Bank, 3(80).

Jakubowska, A. (2017). Zaufanie i asymetria informacji w relacjach podmiotów na rynku finansowym- wybrane aspekty na przykładzie banków i ich interesariuszy. Zeszyty Naukowe Politechniki Śląkiej, 1992, https://www.polsl.pl/Wydzialy/ROZ/ZN/Documents/z113/Jakubowska\%20A.pdf (dostęp 03.03.2021).

Jurevičiene, D. and Skvarciany, V. (2013). The concept of confidence in bank. The 7thInternational Days of Statistics and Economics, Prague, https://www.researchgate.net/publication/264746430_THE_CONCEPT_OF_CONFIDENCE_IN_BANK (dostęp 19.01.2021). 
KPMG (2019). Czy klient jest najważniejszy? Na bank! Analiza doświadczeń klienckich oferowanych przez banki w Polsce, https://assets.kpmg/content/dam/kpmg/pl/pdf/2019/10/pl-raportkpmg-pt-czy-klient-jest-najwazniejszy-na-bank.pdf (dostęp 07.03.2021).

Lee, K.C. and Chung, N. (2009). Understanding factors affecting trust in and satisfaction with mobile banking in Korea: A modified DeLone and McLean's model perspective, Interacting with Computers, 21(5-6), p. 3-4, https://www.researchgate.net/publication/262162793_Understanding_factors_affecting_trust_in_and_satisfaction_with_mobile_banking_in_Korea_A_modified_DeLone_and_McLean\%27s_model_perspective (dostęp 26.01.2021).

Młodzik, L. (2018). Zaufanie jako kluczowa wartość organizacji publicznych w świetle badań żołnierzy zawodowych Wojska Polskiego. Marketing i Zarzadzanie, 1(51).

Orlicka, J. (2015). Zakaz stosowania klauzul abuzywnych i missellingu w znowelizowanej ustawie o ochronie konkurencji i konsumentów. Prawo asekuracyjne, 4(85), http://prawoasekuracyjne.polbrokers.pl/wp-content/uploads/2017/08/pdf_orlicka_4_2015.pdf (dostęp 15.02.2021).

Ostrowska- Dankiewicz, A. (2019). Consumer protection policy in the Polish life insurance market in the aspect of current legal regulations. Investment Management and Financial Innovations, $16(4)$.

Paduszyńska, M. (2019). Misselling jako nadużywanie zaufania klienta na rynku finansowym. Annales. Ethics in Economic Life, 22(3), http://www.annalesonline.uni.lodz.pl/ archiwum/2019/2019_3_paduszynska_45_60.pdf (dostęp 07.03.2021).

Raczkowski, K. i Markiewicz, A. (2015). Wpływ asymetrii informacji w sektorze finansowym na zarządzanie w systemie gospodarczym. W: K. Raczkowski, red., Zarządzanie w systemie gospodarczym. Szanse i zagrożenia. Warszawa: Wolters Kluwer.

Radziszewski, E. (2013). Bank jako instytucja zaufania publicznego. Gwarancje prawne i instytucjonalne. Warszawa: KNF, https://www.knf.gov.pl/knf/pl/komponenty/img/Bank\%20 jako\%20instytucja\%20zaufania\%20publicznego_36396.pdf (dostęp 26.01.2021).

Regulation (EU) 2019/876 of the European Parliament and of the Council of 20 May 2019 amending Regulation (EU) No 575/2013 as regards the leverage ratio, the net stable funding ratio, requirements for own funds and eligible liabilities, counterparty credit risk, market risk, exposures to central counterparties, exposures to collective investment undertakings, large exposures, reporting and disclosure requirements, and Regulation (EU) No 648/2012, OJ L 150.1, 7.6.2019.

Regulation (EU) No 575/2013 of the European Parliament and of the Council of 26 June 2013 on prudential requirements for credit institutions and investment firms and amending Regulation (EU) No 648/2012, OJ L 176, 27.6.2013.

Rzecznik Praw Obywatelskich (2013). Osoby starsze na rynku ustug finansowych - analiza i zalecenia. Warszawa: Zasady Równego Traktowania. Prawo i Praktyka, https://www.rpo.gov.pl/ sites/default/files/Osoby\%20starsze\%20na\%20rynku\%20us\%C5\%82ug\%20finansowych.\%20Analiza\%20i\%20zalecenia_0.pdf (dostęp 08.03.2021).

Skvarciany, V. and Jurevičienè, D. (2018). Factors Influencing Individual Customers Trust in Internet Banking: Case of Baltic States. Sustainability, 10(12), 4809, https://www.researchgate.net/publication/329741245_Factors_Influencing_Individual_Customers_Trust_in_Internet_Banking_Case_of_Baltic_States (dostęp 26.01.2021).

Stolper, O. (2018). It takes two to Tango: Households' response to financial advice and the role of financial literacy. Journal of Banking and Finance, 92.

Tripp, E. (2015). How to Restore Public Trust in Banking. Ivey Business Journal, January/February, https://iveybusinessjournal.com/how-to-restore-public-trust-in-banking/ (dostęp 14.01.2021).

Ustawa z dnia 29.08.1997 r. Prawo Bankowe, tj. Dz.U. 2020, poz. 1896, 2320, 2419.

[www1] http://wiep.pl/instytucja-zaufania-publicznego-encyklopedyczne/ [dostęp 19.01.2021].

Przyjęto/Accepted: 05.07.2021 Opublikowano/Published: 30.09 .2021$. 